\title{
The Influence of Hydrodynamics on the Spatial and Temporal Variation of Phytoplankton Pigments in a Large, Sub-Tropical Coastal Lake (Brazil)
}

\author{
Luciana de Souza Cardoso and David da Motta Marques * \\ Instituto de Pesquisas Hidráulicas - IPH; Universidade Federal do Rio Grande do Sul - UFRGS; Av. Bento \\ Gonçalves, 9500; C. P. 15029; 91501-970;dmm@iph.ufrgs.br; Porto Alegre-RS - Brazil
}

\begin{abstract}
This study evaluated the spatial and temporal distribution of phytoplankton pigments in Itapeva Lake and its relationship with hydrodynamic aspects. Regarding spatial distribution, a decreasing $N \rightarrow S$ gradient was generally observed for the pigments, except in summer. This inversion observed during the summer was influenced by the predominant fetch $(N-E)$. The horizontal heterogeneity was proved (ANOVA) for all seasons of the year, except spring. Spatially in spring, the vertical variance was much more significant $(p<0.05)$ than the horizontal one. The sampling shifts presented a permanent degree of variability among the seasons of the year, showing the existence of a diurnal cycle in the concentration of chlorophyll a. This behavior was related to the fetch, mainly from the NE and SW quadrants, disturbing the system because it is a shallow lake. This confirmed the influence of the Itapeva Lake's hydrodynamic regime on the spatial-temporal distribution of the phytoplankton pigments.
\end{abstract}

Key words: Pigment, phytoplankton, shallow lake, hydrodynamics, wind, bloom

\section{INTRODUCTION}

The applicability of pigment measures in aquatic ecosystems has already been extensively mentioned (Vollenweider, 1974; CETESB, 1990; APHA, 1992). Chlorophyll $a$ is the most abundant and important pigment in living material, therefore there is more information about it (Vollenweider, 1974). The presence or absence of several photosynthetic pigments is used, among other characteristics, to separate groups of algae (HolmHansen and Riemann, 1978; APHA, 1992). Empirical models based on regression between chlorophyll $a$ and total phosphorus have been used for three decades to estimate the algal biomass in lakes. The prognostic model of chlorophyll $a$ is an important tool for the management of Carapebus Lagoon (State of Rio de Janeiro), since it enables the prediction of the algal biomass in response to the inputs of nutrients and seawaters, resulting from human activity (Atayde and Bozelli, 1999). Well-established relations in deep lakes are often valueless in shallow ones. Although the chlorophyll $a$ concentration in shallow lakes is widely used as an estimator of the phytoplankton biomass, its general validity has not been submitted to detailed studies (Vöros and Padisák, 1991). In shallow waters with considerable resuspension of bottom sediments, when zooplankton grazers are abundant, or in samples from the aphotic zone, chlorophyll $a$ derivatives may consist predominantly of pheophytin $a$ and/or

\footnotetext{
* Author for correspondence
} 
pheophorbide $a$ (pheopigments) (Moed and Hallegraeff, 1978). There is also a possibility that the high correlation between pheopigment and zooplankton is due to grazing on pigment-rich phytoplankton cell detritus (Glooschenko et al., 1972). Lorenzen (1967) also called attention to a higher concentration of pheopigments in coastal areas where the wave action may resuspend bottom particles or keep the latter suspended. A strategy to sample shallow lakes typically assumes that the water columns are homogeneous. It is limited to one or a few depths of the water column isothermal portions, and excluding the bottom or waters close to it. This exclusion may contribute to the loss of information about the occurrence of a meroplanktonic algal maximum (MAM) in other systems with shallow euphotic zones or weakly stratified water columns. Thus, the occurrence of a MAM may be a common and important component of biomass in shallow productive lakes (Carrick et al., 1993). Research on the spatial variation of phytoplankton pigments in lakes, generally involved a large sampling network in the water body (Jarry et al., 1991). On the other hand, these data could also be grouped into mean values by compartments in the lagoon itself, because of the morphometry, as occurred in Saquarema Lagoon, Rio de Janeiro (Moreira, 1989). These spatial variations generally occur as a function of different water inflows from rivers or the sea, in the case of most coastal lagoons (Moreira, 1989; Jarry et al., 1991). In this study, the spatial and temporal variation of pigments as a function of a hydrodynamic regime that is strongly driven by the wind, was investigated in the Itapeva Lake (RS, Brazil).

\section{STUDY AREA}

Itapeva Lake is the first $(\mathrm{N} \rightarrow \mathrm{S})$ in a system of interconnected freshwater coastal lakes on the North Coast of the State of Rio Grande do Sul, Brazil (Fig. 1). It has an elongated shape $(30.8 \mathrm{~km}$ $\mathrm{x} 7.6 \mathrm{~km})$, a surface area of $\approx 125 \mathrm{~km}^{2}$ and maximum depth of $2.5 \mathrm{~m}$, and is thus characterized as a shallow lake.

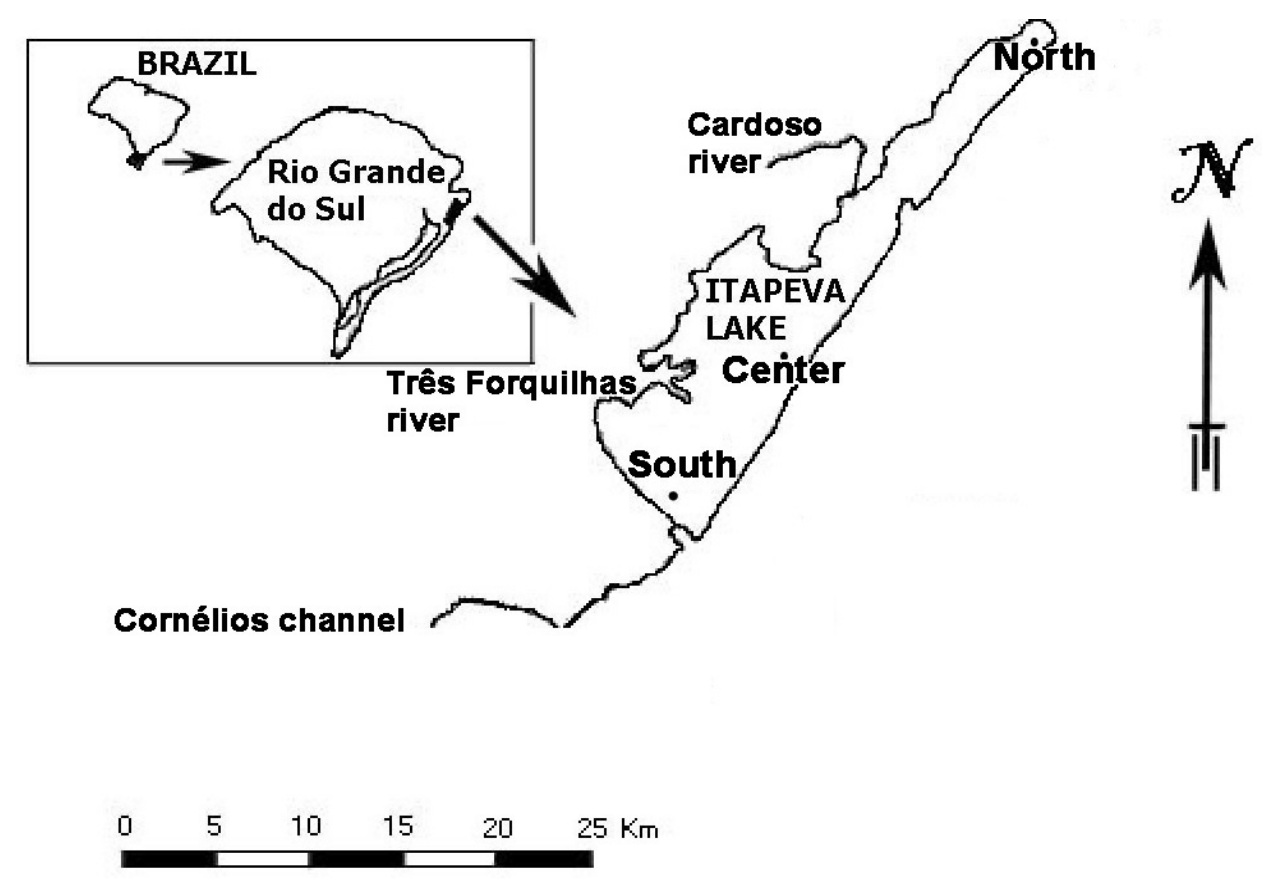

Figure 1 - Study area with sampling stations (North point, Center point and South point). 
The basic hypothesis that the wind acts as a main determinant factor of hydrodynamics from Itapeva Lake was tested by Cardoso (2001) and Cardoso et al. (2003). The predominant wind direction in the area was between the quadrants NNE-ENE and SW-W. NE winds happened in all seasons, while SW winds were absent only during the summer. The calculated effective fetch helped to understand the wind driven hydrodynamics effect on each sampling point in the Itapeva Lake. Wind speeds (mean and maximum) always presented high values (5.04 to $8.65 \mathrm{~m} . \mathrm{s}^{-1}$ ). However, the arrival of a strong cold front in the area during the autumn (May/1999) produced the maximum value for the study period $\left(22.2 \mathrm{~m} . \mathrm{s}^{-1}\right)$. The hydrological variables analyzed and modeled presented a very characteristic seasonal behavior at each sampling point of the Itapeva Lake, closely related to the wind (speed and direction). The water level responded very directly to wind action, since NE winds displaced water from North to South, the main lake axes. On the other hand, winds from SW quadrant produced the opposite effect.

\section{MATERIAL AND METHODS}

The analysis of pigments (chlorophyll $a$ and pheopigments) was performed for three sampling stations in the lake (Fig.1), during four daytime shifts (6 am, 10am, 2pm and $6 \mathrm{pm})$ and at three depths (surface, middle and bottom), in seasonal scale (December/98 to August /99) for three days. Environmental data from the meteorological station (DAVIS, Weather Wizard III, Weather Link) installed at the Center point were recorded every 30 minutes (beginning $24 \mathrm{~h}$ before the campaigns) throughout the period (Cardoso, 2001).

The methodology used followed by APHA (1992) and CETESB (1990). Water collection at each depth was performed with a Van Dorn horizontal bottle. For each sample, a volume of $250 \mathrm{~mL}$ of water in a fiberglass filter (Ahlstrom $\mathrm{n}^{\circ} 151$ and $0.7 \mu \mathrm{m}$ porosity), was vacuum filtered, and immediately frozen and kept dry in the dark until the extractions for readings (Bausch and Lomb Spectronic 1001 spectrophotometer). Acetone at $90 \%$ was used as an extraction solvent. A trichromatic equation with readings at the following optical densities 750, 664, 647 and 630 $\mathrm{nm}$, was used to determine chlorophyll $a$; while, a monochromatic equation was used to determine pheophytin $a$ at wavelengths 750,665 and $664 \mathrm{~nm}$. In order to read pheopigments, $0.1 \mathrm{~mL}$ of $\mathrm{HCl} 0.1$ $\mathrm{N}$ was added to the sample itself in the cuvette (optical pathway of $1 \mathrm{~cm}$ ).

The spatial and temporal variation analysis were carried out by ANOVA three-way repeated measures, both for the effect of sampling shifts and for the water column profile. It was thus possible to determine not only the occurrence of spatial and/or temporal heterogeneity in the distribution of pigments, but also which factor or factors were responsible for this effect and, above all, at what time of the year. Descriptive analysis and analysis of variance (ANOVA) were carried out using the STATISTICA ${ }^{\circledR}$ program.

The Principal Components Analysis (PCA) (Jongman et al., 1987) was performed to establish relationships between the pigments distribution and hydrodynamic variables (water level, wind direction, maximum and medium wind velocity), during the sampling period. Correlation was the cross-products matrix in PCA and calculate scores for variables by weighted averaging. The program used was PCORD4®.

\section{RESULTS AND DISCUSSION}

Spring (Dec/1998) was the season with the highest chlorophyll $a$ contents (5.2 to $102.5 \mu \mathrm{g} . \mathrm{L}^{-1} ; 34.7$ $\mu \mathrm{g} . \mathrm{L}^{-1}$ on average), while the lowest mean and smallest standard deviation were recorded in summer (Mar/1999) (1.9 to $29.3 \mu \mathrm{g} . \mathrm{L}^{-1} ; 7.7 \mu \mathrm{g} . \mathrm{L}^{-1}$ on average) (Fig. 2). Considering the sampling stations, the highest concentrations of chlorophyll $a$ were found in the North, while, generally the opposite occurred in the South (an exception was recorded in summer) (Fig. 2). This result suggested the existence of a decreasing $\mathrm{N} \rightarrow \mathrm{S}$ gradient. The atypical gradient behavior during the summer was related to wind direction, predominantly between the N-E quadrants, suggesting two hypotheses: (1) phytoplankton with its pigment possibly being transported windward and accumulating in the South, and/or (2) the nutrients and solids could possibly be transported and favor an improved physiologic status of the phytoplankton community on the lake southern side, by means of a larger nutrient supply and/or shading (avoiding the destructive photo-oxidation of chlorophyll). In fact, nutrients and solids also exhibited a rising gradient in the $\mathrm{N} \rightarrow \mathrm{S}$ direction 
during summer (Cardoso, 2001; Cardoso et al., 2003). However, the density gradient of the phytoplankton community (Cardoso, 2001) was the opposite (decreasing from $\mathrm{N} \rightarrow \mathrm{S}$ ). But in the North cyanobacterias predominated $(>50 \%)$, while in the South bacillariophytes was predominant $(>50 \%)$. We know that diatoms have silica frustules and their sinking rate is faster than that of cyanobacterias (since these present a mucilaginous sheat and/or aerotopes to keep afloat), and they are generally more abundant at the bottom. Thus, NE direction winds provoke a resuspension effect of the particles deposited at the bottom (diatoms and nutrients), this effect being more visible from $\mathrm{N} \rightarrow \mathrm{S}$. Indeed in this sense, the wind effect was decisive both in the spatial distribution of the phytoplankton community in Itapeva Lake and in their physiological/nutritional state.

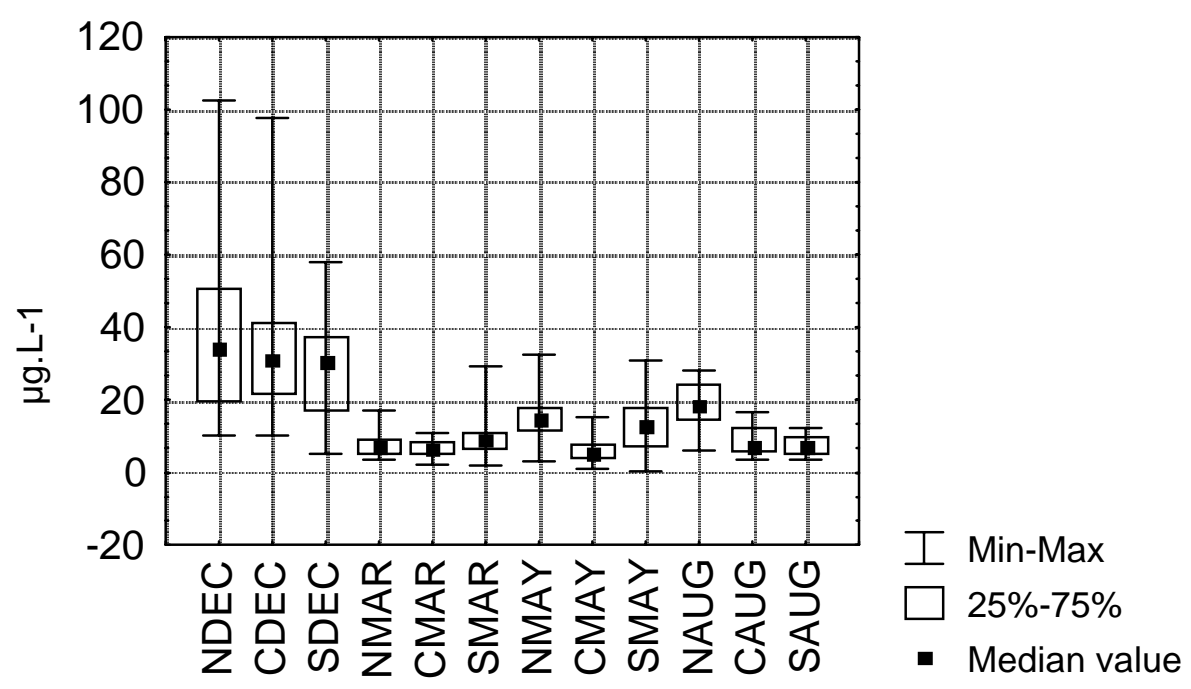

Figure 2 - Distribution of the chlorophyll $a$ values $\left(\mu \mathrm{g} . \mathrm{L}^{-1}\right)$ at each sampling point and month in Itapeva Lake (N=North. $\mathrm{C}=$ Center, $\mathrm{S}=$ South. $\mathrm{DEC}=$ December/1998, MAR= March/1999, MAY= May/1999, AUG= August/1999).

Anderson (1986 apud Moon and Dunstan, 1990) indicated that the presence of chlorophyll peaks in the Chesapeake Bay tributaries was not related to anthropogenic sources of nutrients. It was also suggested that the chlorophyll peak was caused by a hydrodynamic trap, the same mechanism involved in the formation of maximum turbidity in partly mixed estuaries. It was suggested that diatoms were selectively imprisoned in the maximum turbidity zone, because their high sinking rates were almost the same as those of the vertical currents in the "null" zone (Moon and Dunstan, 1990).
Normally, the highest concentrations of chlorophyll $a$ (mean and maximum values) occurred at the surface of the three sampling stations (mean values during the studied period of $21.6 \mu \mathrm{g} . \mathrm{L}^{-1}$ for the North, $14.6 \mu \mathrm{g} . \mathrm{L}^{-1}$ for the Center and $16.7 \mu$ g.L. $L^{-1}$ for the South) (Fig. 3).

In the analysis of variance (ANOVA) performed to verify the homogeneity in the water column, it was found that spring $(\mathrm{p}<0.05)$ was the only season in which profile variance was significant. During this season there was a strong effect of the sampling day $(p<0.05)$, both associated to the time and to the sampling station as influencing factors. 
DEC/1998

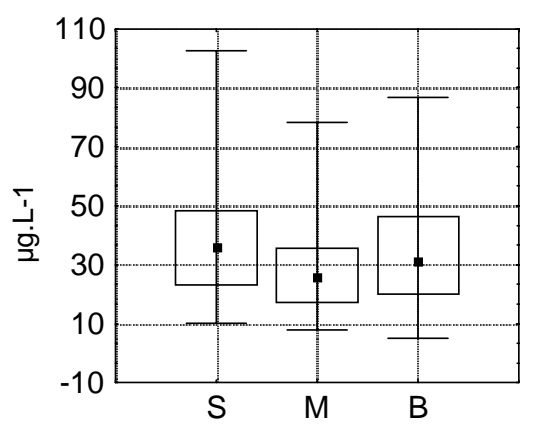

MAY/1999

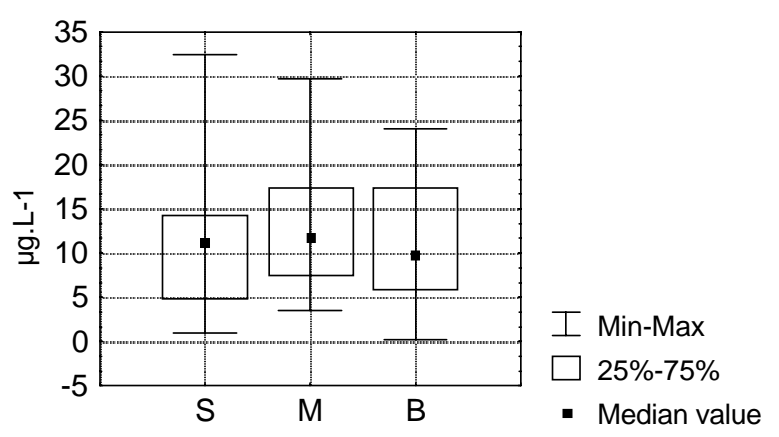

MAR/1999

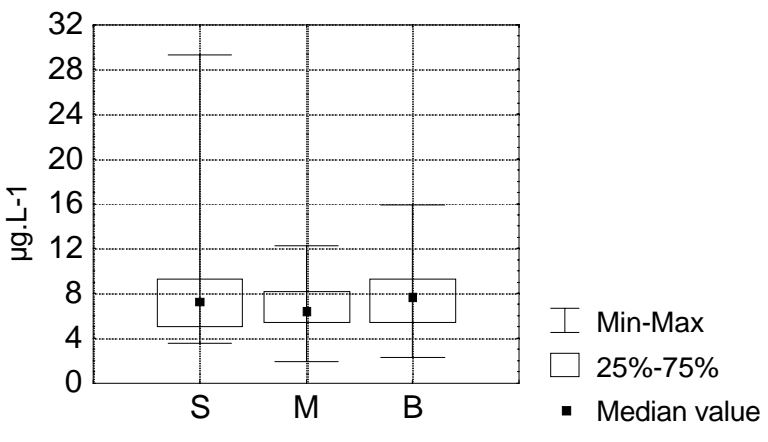

AUG/1999

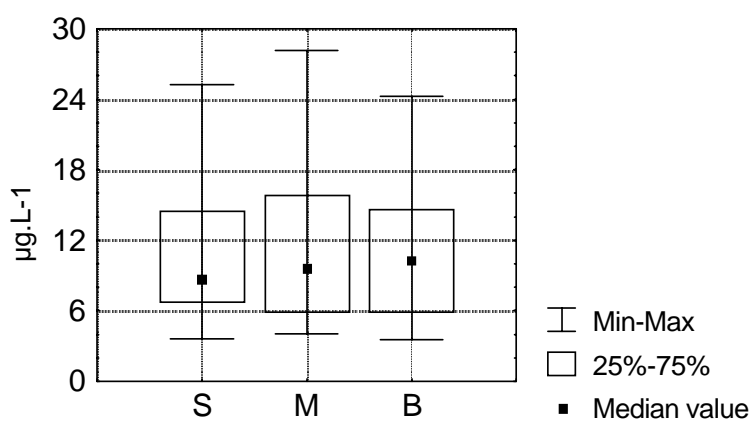

Figure 3 - Distribution of the chlorophyll $a$ values $\left(\mu \mathrm{g} . \mathrm{L}^{-1}\right)$ in the profile of each seasonal sampling in Itapeva Lake. ( $\mathrm{S}=$ Surface, $\mathrm{M}=$ Middle, $\mathrm{B}=$ bottom, DEC/1998= Spring, MAR/1999= Summer, MAY/1999= Autumn, AUG/1999= Winter).

In summer, none of the combinations of factors tested presented a significant variance. In autumn, the day $(\mathrm{p}<0.05)$ and the sampling station $(\mathrm{p}<0.01)$, were the factors that presented significant variances, when analyzed together or associated with time as a factor. In winter, also, the sampling station $(\mathrm{p}<0.001)$ and the day $(p<0.05)$ were the factors that presented significant variances, but the day was only significant when associated to the sampling station.

The existence of horizontal heterogeneity during the cold seasons (autumn and winter) was verified as to the temporal scale (day sampling). In summer, the system behaved homogeneously between the sampling stations in relation to vertical distribution, while a vertical stratification between the sampling days was heterogeneous only in spring. In fact, in the coastal area of Rio Grande do Sul, spring was characterized by a constant oscillation of wind velocity and direction, disturbing the water column to such an extent that a complete vertical homogeneity was impossible, distinct strata of this water mass being maintained (Cardoso, 2001; Cardoso et al., 2003).

A relationship such as that described by Carrick et al. (1993) with chlorophyll proportions of MAM for the surface varying from 10 to 24 was not obtained in this study (maximum around 4 for the Dec/1998 sampling), due to the non-existence of a significant vertical variance. Even during autumn, in the South, when the maximum concentration was generally recorded at the bottom, the MAM was lower than that recorded in the Center. Once again, its characteristic as a shallow environment strongly influenced by wind action, accounted for the low-concentration of bottom material which instead moved vertically and horizontally according to the hydrodynamics. Certainly, the longer permanence of active phytoplankton in the surface layers may also be related to the low transparency of the water column, which does not allow a photosynthetically active community to remain at the bottom for a long time. A maximum amount of chlorophyll at the bottom is not found in very turbid waters or when the 
picnocline is deep or absent (Anderson, 1969 apud Abbott et al., 1984).

The existence of a diurnal variation was seasonally characteristic (Fig. 4). In the warmer seasons, i.e. spring (Dec/1998) and summer (Mar/1999), a higher concentration of chlorophyll $a$ was found during the warmer shifts of the day (10am and $2 \mathrm{pm})$. However, for the colder seasons, autumn (May/1999) and winter (Aug/1999), higher concentrations were recorded during the afternoon shifts (2pm and $6 \mathrm{pm})$.

\section{DEC/1998}

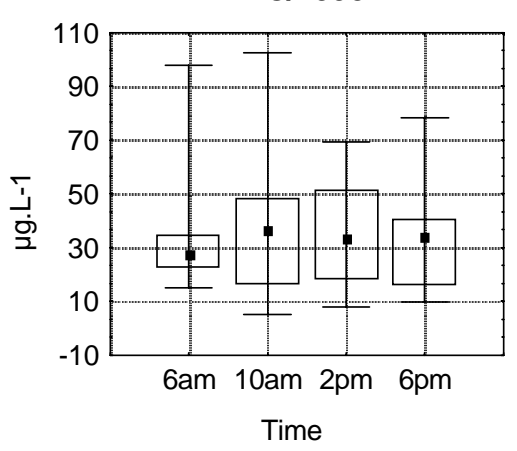

MAY/1999

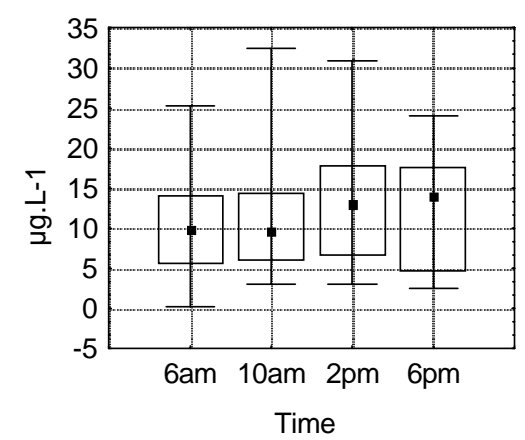

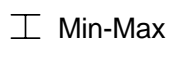

$25 \%-75 \%$

- Median value

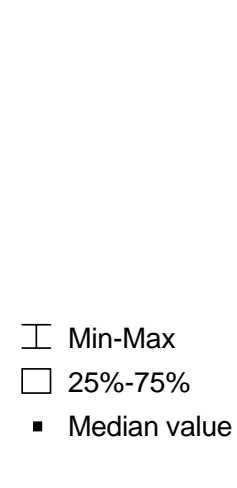

MAR/1999

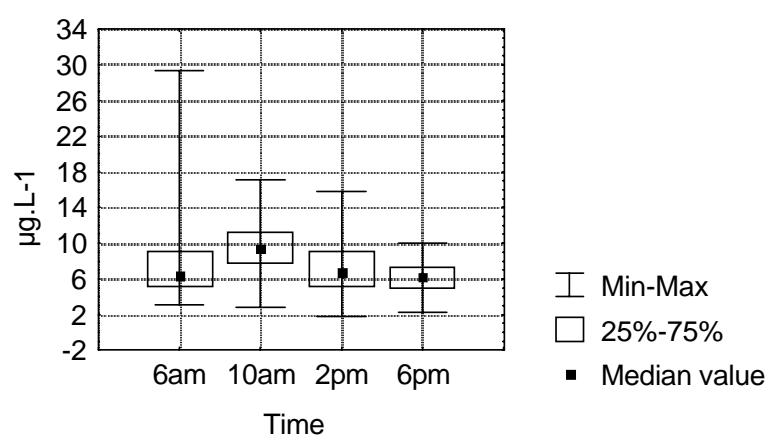

AUG/1999

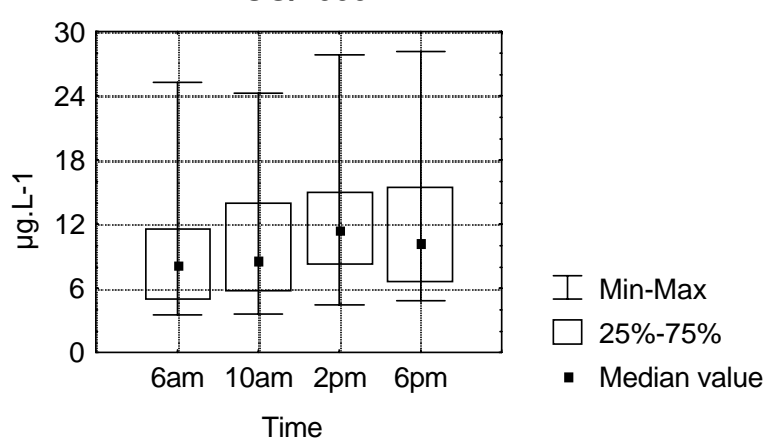

Figure 4 - Distribution of the diurnal chlorophyll $a$ values $\left(\mu \mathrm{g} . \mathrm{L}^{-1}\right)$ during each seasonal sampling in Itapeva Lake. (T= time of the sampling shift, DEC/1998= Spring, MAR/1999= Summer, MAY/1999= Autumn, AUG/1999= Winter)

In order to verify the existence of a diurnal cycle in the pigment concentration, the variance between the sampling shifts (time) was tested in the seasonal samplings. In spring, significant variances occurred between sampling days $(\mathrm{p}<0.01)$ and in the interaction between sampling stations and time $(\mathrm{p}<0.05)$, both when associated to the water column profile as a factor. In summer, a major variance was observed between the sampling shifts $(\mathrm{p}<0.001)$, independent of the factors tested. Thus, during this season, the effect of diurnal variability was more important than during the other seasons. Furthermore, a significant horizontal variability was now found among the sampling stations $(\mathrm{p}<0.01)$, proving the existence of the gradient at this time of the year, and not only in the cold seasons as in the previous analysis. In autumn, the day $(\mathrm{p}<0.05)$ and the sampling station $(\mathrm{p}<0.001)$ were the factors that presented the greatest variance in the chlorophyll $a$ values, and they interacted with the sampling shift. In winter, the point $(\mathrm{p}<0.001)$ and the sampling shift $(p<0.01)$ once again presented a significant variability when associated to the profile as a factor. Thus, the sampling shifts always presented a degree of variability at all seasons of the year, showing the existence of a diurnal cycle involving chlorophyll $a$ concentration. Certainly, the strong effect observed during the summer was closely related to diurnal and daily variations in the physical and chemical variables of the water as temperature, $\mathrm{pH}$ and oxygen dissolved (Cardoso, 
2001). These variables showed low values during morning growing up to afternoon and decline to night again.

According to Aleixo (1981), the homogeneous or non-homogeneous distribution of chlorophyll $a$ must be related to diurnal or seasonal temperature cycles; thermal discontinuities tend to delimit differently populated strata. With the absence of thermal stratification, the nutrients captured in the hypolimnion are released to the epilimnion, enabling greater development of the phytoplankton. Since Itapeva Lake is a shallow, polymictic environment, stratification periods are rather rare and ephemeral. However, heterogeneity, either longitudinal or vertical, occurred as a function of the hydrodynamic regime.

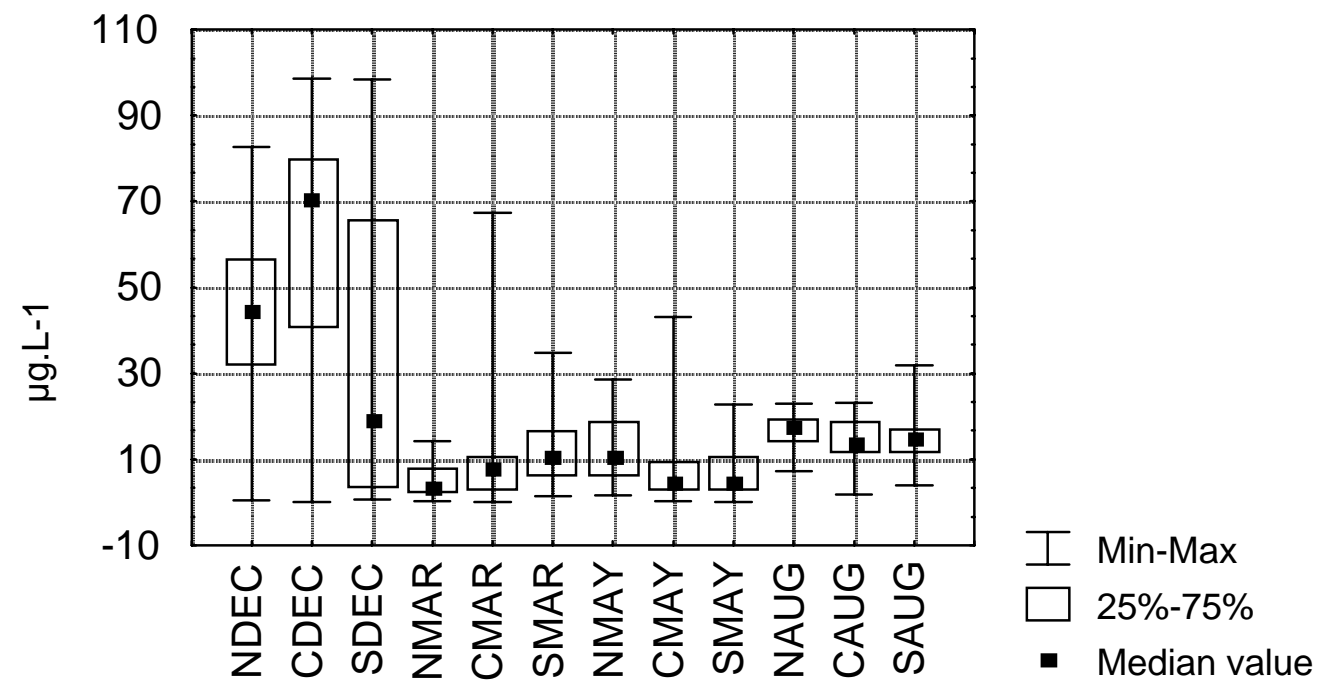

Figure 5 - Distribution of pheopigment values $\left(\mu \mathrm{g} . \mathrm{L}^{-1}\right)$ at each sampling stations in Itapeva Lake $(\mathrm{N}=$ North, C=Center, S=South, DEC $=$ December/1998, MAR= March/1999, MAY= May/1999, AUG= August/1999).

For the pheopigment values (Fig. 5), spring was also the season with the highest values (0.02 to $98.6 \mu \mathrm{g} . \mathrm{L}^{-1} ; 43.0 \mu \mathrm{g} . \mathrm{L}^{-1}$ on average) and the lowest mean was recorded in summer $\left(0.0\right.$ to $67.4 \mu \mathrm{g} . \mathrm{L}^{-1}$; $8.7 \mu \mathrm{g} . \mathrm{L}^{-1}$ on average). On the other hand, the smallest standard deviation occurred in winter.

The decreasing gradient in the $\mathrm{N} \rightarrow \mathrm{S}$ direction was observed only in autumn-winter and the opposite occurred in summer, probably due to the same factors mentioned previously for chlorophyll. However, during spring the highest concentration occurred at the Center. Certainly, this highest accumulation of pheopigments was related to wind direction. Although it had presented a broad range of oscillations during that season, the wind had the highest frequency towards direction $\mathrm{W}$, producing a more intense fetch effect in the Center (Cardoso, 2001; Cardoso et al., 2003).
The vertical spatial distribution (Fig. 6) was homogeneous during the summer and winter for pheopigment values in the lake, but a clear gradient was found in the water column during spring and slightly in autumn.

The analysis of variance (ANOVA) performed to verify whether there was or not homogeneity in the water column indicated only autumn as the season when the effect of the profile on the pheopigments concentration was significant $(p<0.05)$. This effect was only found when interacting with the day and sampling shift simultaneously, or with the sampling station and sampling day separately. Unfortunately, during spring and summer, the effects on the water column could not be tested with the combination of factors, due to the gaps left by the negative and/or extremely high values. However, when the value was tested again individually, in summer the 
sampling station $(\mathrm{p}<0.01)$ presented a significant variation. Thus, the significant variance of pigment concentration (chlorophyll $a$ and pheopigments) among the sampling stations, suggested the strong influence of the dominant wind regime during the summer. Although in spring there was a visible pheopigment gradient in the water column (Fig. 6), the non-confirmation of this significant variation may have occurred as a result of the $\mathrm{N}$-amostral having become smaller, as mentioned above.

A diurnal variation related to the pheopigments did not show any definite pattern, where only a broad variation of these values was found at the beginning and end of the day during spring (Fig.7).
DEC/1998

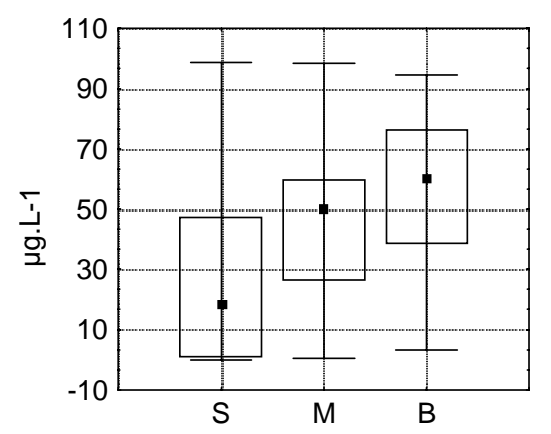

MAY/1999

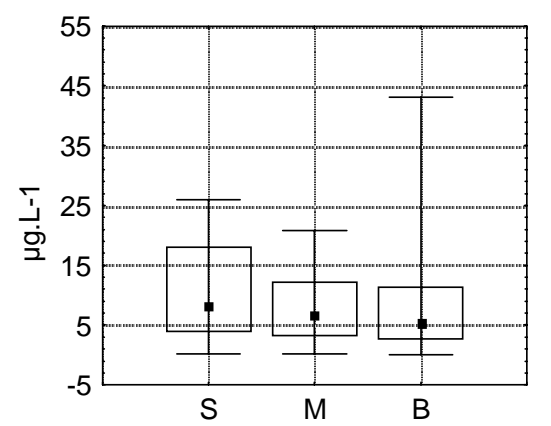

I Min-Max

$\square$ 25\%-75\%

- Median value

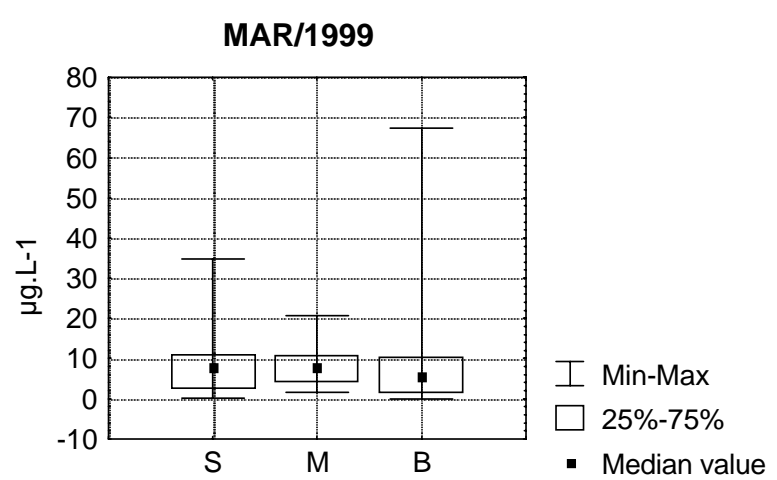

AUG/1999

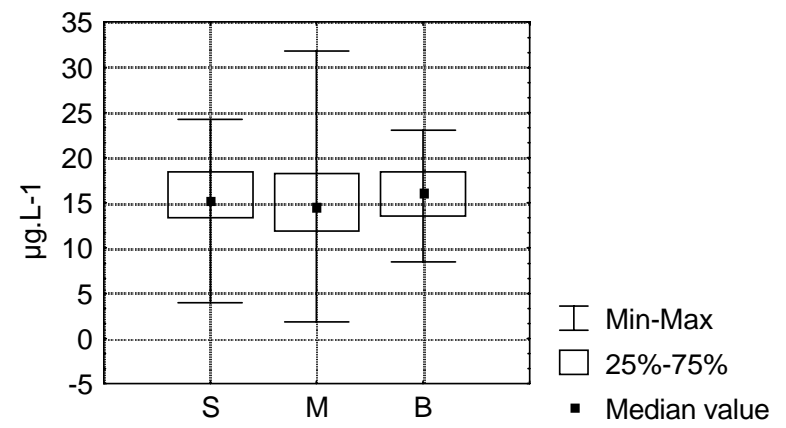

Figure 6 - Distribution of the pheopigment values $\left(\mu \mathrm{g} . \mathrm{L}^{-1}\right)$ in the profile of each seasonal sampling in Itapeva Lake $(\mathrm{S}=$ Surface, $\mathrm{M}=$ Middle, $\mathrm{B}=$ bottom, DEC/1998= Spring, MAR/1999= Summer, MAY/1999= Autumn, AUG/1999= Winter).

A diurnal cycle of pheopigment concentration was only seen in winter with the sampling station interaction $(p<0.05)$. During the other seasons, the combination between factors could not be tested due to the same problems mentioned previously. However, testing the factors individually (one-way ANOVA) we found significant variances for the sampling point once again in summer $(p<0.05)$, and for the sampling days in autumn $(\mathrm{p}<0.001)$. This variance of the pheopigment concentration among the days in autumn is probably related to the bloom of Anabaena circinalis, recorded during this period (Cardoso, 2001).
According to Aleixo (1981) the highest pheophytin concentration in the Vale do Rio Doce/MG lakes during spring may have been the result of a greater decomposition of organic matter contained in the lake due to higher temperatures. The degradation of the macrophyte leaves containing chlorophyll could influence the chlorophyll a/pheophytin balance, favoring an increase in the latter pigment in the lake. In shallow lakes the water masses are influenced by stronger solar radiation, favoring organic matter decomposition processes, reflecting on pheophytin concentrations. Itapeva Lake presents a narrow strip of Cyrpus californicus only on its borders. 
However, greater inputs may have occurred from the drainage basin, where the water runoff from the mountains also brought with it a larger amount of plant detritus (remnants of tissues and pollen grains observed in the quantitative plankton samples). Another major reason may be associated with mechanical disturbances that occurred in the phytoplankton cells due to the wind action from different directions at short time intervals. Besides this, carotenoids found in natural diatom populations interfere in the spectrophotometric method for chlorophyll $a$ and pheopigments, especially due to spectral changes in the acidifying fucoxanthine (Riemann, 1978). During spring the bacillariophytes were the dominant group in Itapeva Lake (Cardoso, 2001; Cardoso et al., 2003).

\section{DEC/1998}

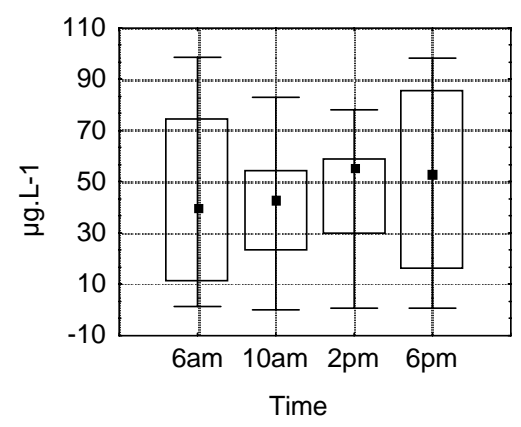

MAY/1999

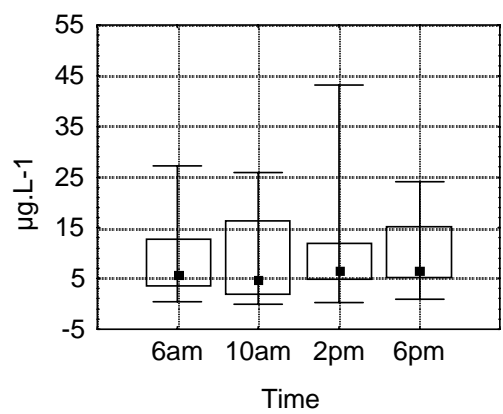

工 Min-Max

$25 \%-75 \%$

- Median value

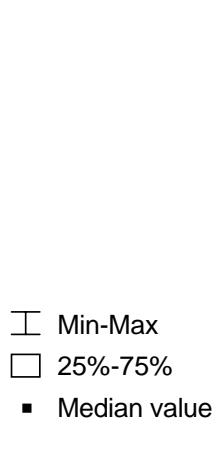

MAR/1999

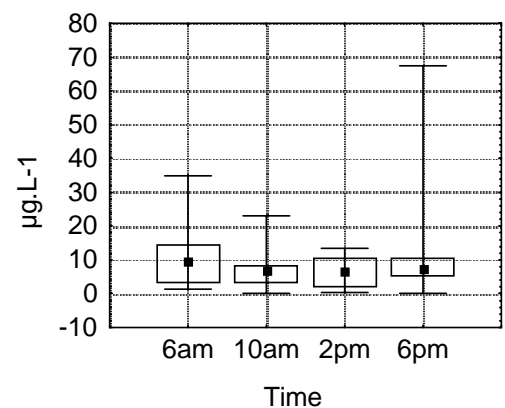

AUG/1999

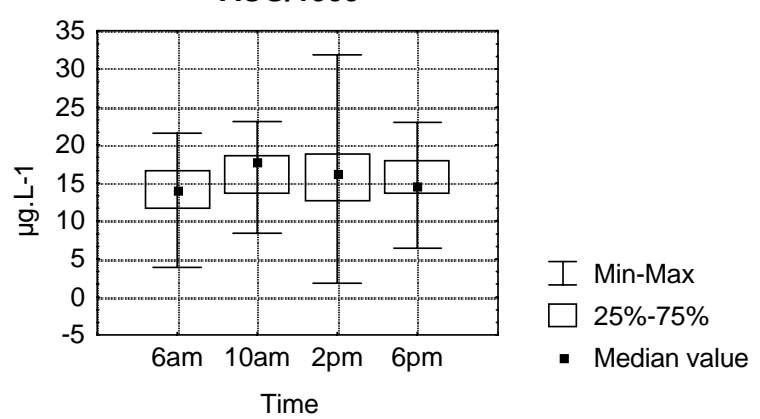

Figure 7 - Diurnal distribution of pheopigment values $\left(\mu \mathrm{g} . \mathrm{L}^{-1}\right)$ during each seasonal campaign at Itapeva Lake ( $\mathrm{T}=$ time of the sampling shift, DEC/1998= Spring, MAR/1999= Summer, MAY/1999= Autumn, AUG/1999= Winter).

Barbosa et al. (1988) stressed as an important aspect of the annual chlorophyll $a$ variations the fact that there are significantly higher concentrations of pheophytin $a$ throughout the year. It reflected a certain deficiency in the nutritional conditions affecting the physiological status of phytoplankton populations and causing a predominance of "old" cells, therefore, less active at photosynthesis. In fact, this was also observed for Itapeva Lake, except in autumn, when the increased concentration of chlorophyll $a$ over the pheopigments was directly related to cyanobacteria blooms.
The health of phytoplanktonic chlorophyll $a$ is more closely correlated to cell size. Type of limitation, either by light or nutrients, and trophic state may affect the relationship, but other factors, such as taxonomic composition, appear to be less important (Vöros and Padisák, 1991). However, George and Edwards (1976) found that when diatoms and chlorophytes were dominant, chlorophyll $a$ was distributed homogeneously throughout the water column. When there are cyanobacteria blooms, dense accumulations of algae on the surface often appear under calm conditions. At high wind speeds $\left(>6 \mathrm{~m} \cdot \mathrm{s}^{-1}\right)$, cyanobacteria became more homogeneously 
distributed in the water column, since the turbulent mixture overcame the tendency of very floatable cells to remain at the surface. Generally there is a close relationship between the wind-induced turbulence and the development of vertical agglomerates of cyanobacteria. However, for Itapeva Lake, the dominance of diatoms and the higher concentration of chlorophytes in spring occurred when the water column was heterogeneous for chlorophyll $a$. During the cyanobacteria bloom, in autumn, no significantly different distribution of chlorophyll $a$ was found in the water column. Probably due to the more representative variance existing between the sampling stations and the days. Furthermore, the highest concentration of this pigment occurred in the middle of the water column and not at the surface during this period. However, for pheopigments the system was only heterogeneous in autumn. This fact was shown by the development of the bloom during the sampling period, indicating the senescence of these algae along the profile. Thus, it was not possible to generalize the effect of the taxonomic composition on pigment distribution, as had already been raised by Vöros and Padisák (1991). It was only possible to gain a better understanding of the phytoplankton physiology considering the environmental disturbances caused by the wind.

The principal component analysis (PCA) helped to illustrate the effect of hydrodynamics on the spatial-temporal distribution of the phytoplankton pigments. Throughout the study period, the two first axes contributed with $100 \%$ of the data variance.

In spring, the strong effect of wind velocity on the one hand and the frequent windward oscillations contributed to a time gradient between the morning and afternoon shifts (Fig. 8).

\section{Spring - $15 /$ DE C /1998}

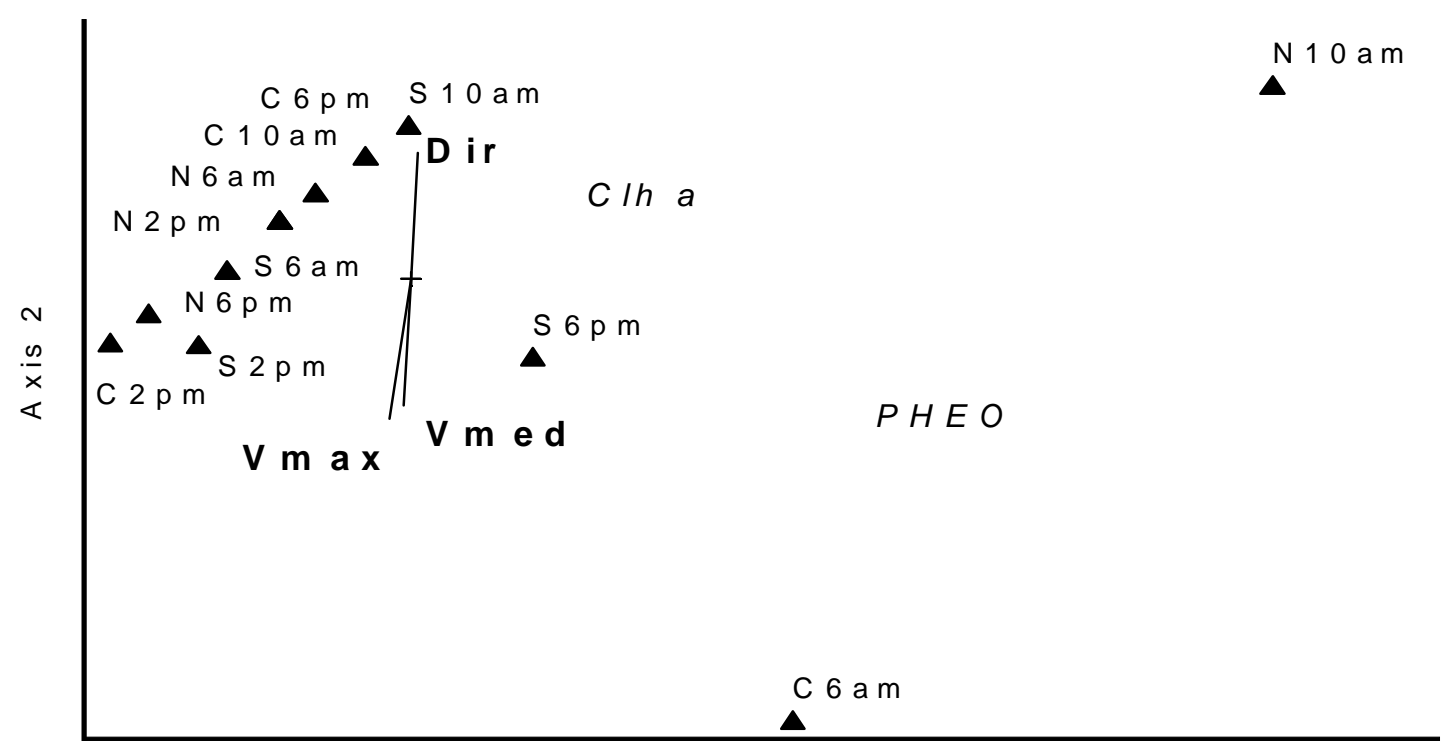

A $x$ is 1

Figure 8 - PCA ranking diagram for phytoplankton pigments and hydrodynamic variables in Itapeva Lake during spring $(\mathrm{N}=$ North, $\mathrm{C}=$ Center, $\mathrm{S}=$ South, $\mathrm{Vmed}=$ wind medium velocity, $\mathrm{Vmax}=$ wind maximum velocity, $\mathrm{Dir}=$ wind direction). 


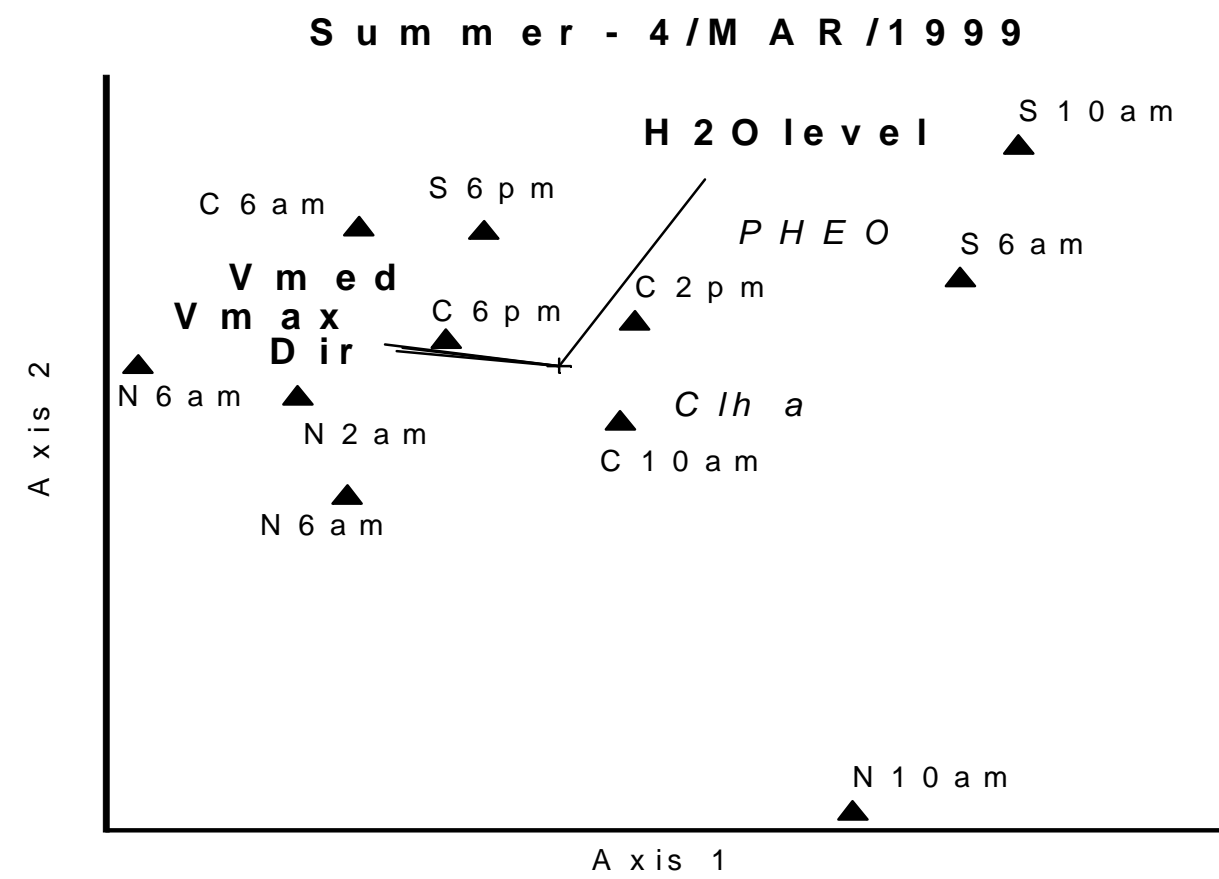

Figure 9 - PCA ranking diagram for phytoplankton pigments and hydrodynamic variables in Itapeva Lake, during summer $(\mathrm{N}=$ North, $\mathrm{C}=\mathrm{Center}, \mathrm{S}=\mathrm{South}, \mathrm{Vmed}=$ wind medium velocity, $\mathrm{Vmax}=$ wind maximum velocity, $\mathrm{Dir}=$ wind direction, $\mathrm{H} 2 \mathrm{Olevel}=$ water level).

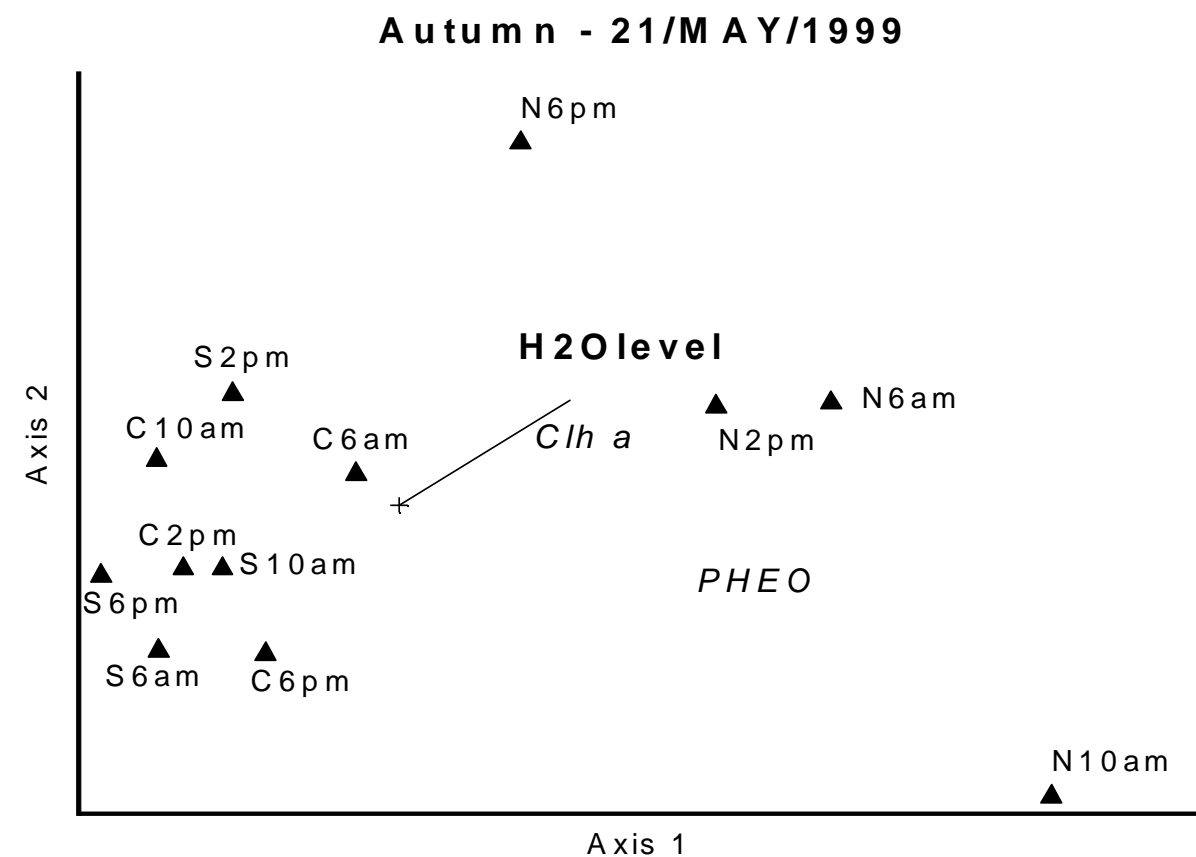

Figure 10 - PCA ranking diagram for phytoplankton pigments and hydrodynamic variables in Itapeva Lake, during autumn ( $\mathrm{N}=$ North, $\mathrm{C}=$ Center, $\mathrm{S}=$ south. H2Olevel= water level). 
Winter - 14/AUG/1999

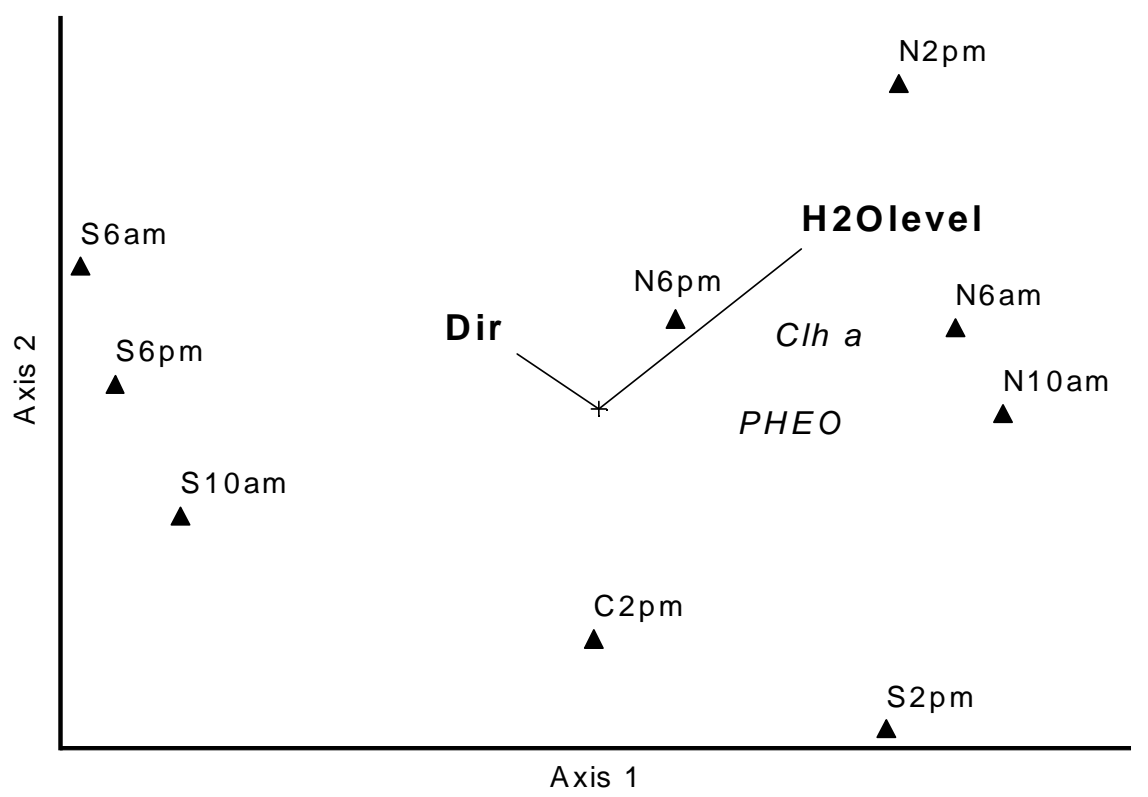

Figure 11 - PCA ranking diagram for phytoplankton pigments and hydrodynamic variables in Itapeva Lake, during winter $(\mathrm{N}=$ North, $\mathrm{C}=\mathrm{Center}, \mathrm{S}=$ South, Dir= wind direction, level= water level).

Table 1 - Pigments values $\left(\mu \mathrm{g} . \mathrm{L}^{-1}\right)$ from coastal lakes of State of Rio Grande do Sul (Chl $a=$ chlorophyll $a$, Pheo= pheopigments).

\begin{tabular}{lr|r|r|r}
\hline \multicolumn{1}{c}{ Aquatic environment } & & min. & \multicolumn{1}{c}{ max. } & \multicolumn{1}{c}{ average } \\
\hline Pombas lake $^{1}$ & Clh $a$ & 0.08 & 23.5 & $4.41(0.4-9.9)$ \\
& Pheo & 0.16 & 193.4 & $43.4(2.9-149)$ \\
Emboaka lake $^{2}$ & Clh $a$ & N D & 2.93 & $1.08(0.26-2.4)$ \\
& Pheo & & & \\
Tramandaí lagoon $^{3}$ & Clh $a$ & 1 & 45 & $6.52(3-15)$ \\
& Pheo & & & \\
Caconde lake $^{4}$ & Clh $a$ Pheo & 5.16 & 40.3 & 11.53 \\
Marcelino lake, & Clh $a$ & 0.56 & 76.8 & $1.8-47.1$ \\
Peixoto lake and & & & & \\
Pinguela lake $^{5}$ & & & & \\
Itapeva lake $^{6}$ & Pheo & 0.89 & 71.4 & $8.0-34.2$ \\
Emboaba lake $^{7}$ & Clh $a$ & 0.26 & 102.49 & $7.65-34.65$ \\
& Pheo & 0.02 & 98.59 & $8.67-43.45$ \\
& Clh $a$ & ND & 9.3 & $0.2-2.5$ \\
\hline
\end{tabular}

Source: ${ }^{1}$ Kremer, $1985 ;{ }^{2}$ Vélez, $1990 ;{ }^{3}$ Medeiros, $1992 ;{ }^{4}$ Konrath, $1995 ;{ }^{5}$ Salomoni, $1997 ;{ }^{6}$ Cardoso, 2001; ${ }^{7}$ Spohr-Bacchin, 1994.

In summer, the constant action of winds from the $\mathrm{NE}$ quadrant enabled an increasing spatial gradient of pigments in the $\mathrm{N} \rightarrow \mathrm{S}$ direction. The close relationship of this behavior was shown by the water level rise in the South in response to the wind, where velocity and direction acted together (Fig. 9).
In autumn, since the fetch effect was from the SW quadrant, a response of the spatial gradient in the opposite direction was found, where the water level was the hydrodynamic variable responsible for that gradient (Fig. 10). In winter, this same behavior can be found for the reasons already explained, but the wind direction provided a 
greater contribution (Fig. 11). In this way, the strong influence of hydrodynamics in a shallow freshwater lake showed to be the key factor in the spatial-temporal distribution of phytoplankton pigments in Itapeva Lake.

Comparing with other coastal lakes in the State of Rio Grande do Sul (Table 1), pigments values from Itapeva lake were very similar to values recorded by Salomoni (1997). Due to the lakes studied by her were included in the same coastal system (lakes inter-connected in north coast of RS), while the others one were isolated lakes or lagoon.

\section{ACKNOWLEDGEMENTS}

We thank the FAPERGS (Fundação de Amparo à Pesquisa no Rio Grande do Sul) and $\mathrm{CNPq}$ (Conselho Nacional de Desenvolvimento Científico e Tecnológico), for the funds allocated to the project. We also thank Prof. PhD. Francisco Barbosa (UFMG), for his constant attention, sending articles of interest for the present study, and the students involved in pigment analysis.

\section{RESUMO}

Este estudo avalia a distribuição espaço-temporal dos pigmentos fitoplanctônicos na Lagoa Itapeva e sua relação com aspectos hidrodinâmicos. Com relação à distribuição espacial, geralmente um gradiente decrescente no sentido $\mathrm{N} \rightarrow \mathrm{S}$ foi observado para os pigmentos, com exceção do verão. Esta inversão observada durante o verão foi influenciada pelo fetch predominante (N-E). Excetuando a primavera, ficou comprovada a existência de heterogeneidade horizontal (ANOVA) nas demais estações do ano. Espacialmente, na primavera a variância vertical foi muito mais significativa $(p<0,05)$ que a horizontal. Os turnos de amostragem sempre exibiram um grau de variabilidade entre as estações do ano, mostrando a existência de um ciclo diurno com relação à concentração de clorofila $a$. Este comportamento esteve relacionado com o fetch principalmente dos quadrantes NE-SW, perturbando o sistema por ser uma lagoa rasa. Com isso, ficou constatada a influência do regime hidrodinâmico da Lagoa
Itapeva na distribuição espaço-temporal dos pigmentos fitoplanctônicos.

Palavras-chave: pigmento, fitoplâncton, lagoa rasa, hidrodinâmica, vento, floração.

\section{REFERENCES}

Abbot, M. R.; Denman, K. L.; Powell, T. M.; Richerson, P. J.; Richards, R. C. and Goldman, C. R. (1984), Mixing and the dynamics of the deep chlorophyll maximum in Lake Tahoe. Limnol. Oceanogr., 29 : (4), 862-878.

Aleixo, R. de C. (1981), Fatores ecológicos, concentração de clorofila a e feofitina em cinco lagos do Vale do Rio Doce, MG: um estudo comparativo. Dissertação (Mestrado), Universidade Federal de São Carlos, São Carlos, SP. 220 pp.

American Public Health Association (1992), Standard Methods for Examination of Water and Wastewater. 18. ed. Washington : APHA. 1268 pp.

Attayde, J. L. and Bozelli, R. L. (1999), Environmental heterogeneity patterns and predictive models of chlorophyll $a$ in a Brazilian coastal lagoon. Hydrobiologia, 390, 129-139.

Barbosa, F. A. R.; Tôrres, G. E. and Coutinho, M. E. (1988), Ciclo anual de temperatura e sua influência nas variações sazonais de alguns parâmetros físicoquímicos e da clorofila e feofitina $a$ na Lagoa Carioca - Parque Florestal do Rio Doce, MG. Acta Limnol. Brasil., 2, 129-151.

Cardoso, L. S. (2001), Variações da estrutura planctônica da Lagoa Itapeva (Sistema Lagunar Costeiro do Rio Grande do Sul) em função da hidrodinâmica. Tese (Doutorado), Universidade Federal do Rio Grande do Sul, Porto Alegre, RS. 466 pp.

Cardoso, L. S.; Silveira, A. L. L. and Motta Marques, D. M. L. (2003), A ação do vento como gestor da hidrodinâmica na lagoa Itapeva (Litoral Norte do Rio Grande Do Sul-Brasil). Revista Brasileira de Recursos Hídricos, 8 : (3), 5-15.

Carrick, H. J.; Aldridge, F. J. and Schelske, C. L. (1993), Wind influences phytoplankton biomass and composition in a shallow, productive lake. Limnol. Oceanogr., 38 : (6), 1179-1192.

Companhia de Tecnologia e Saneamento Ambiental (1990), Determinação de pigmentos fotossintetizantes clorofila $a, b$ e $c$ e feofitina. Método de Ensaio L5.306. São Paulo : CETESB. 22 pp.

George, D. G. and Edwards, R. W. (1976), The effect of wind on the distribution of chlorophyll $a$ and crustacean plankton in a shallow eutrophic reservoir. J. appl. Ecol., 13, 667-690. 
Glooschenko, W. A.; Moore, J. E. and Vollenweider, R. A. (1972), The seasonal cycle of pheo-pigments in lake Ontario with particular emphasis on the role of zooplankton grazing. Limnol. Oceanogr., 17 : (4), 597-605.

Holm-Hansen, O. and Riemann, B. (1978), Chlorophyll a determination: improvements in methodology. Oikos, 30 : (3), 438-447.

Jarry, V.; Frisoni, G. and Legendre, P. (1991), Organisation spatiale et modélisation écologique d'um peuplement phytoplanctonique de lgune (étang de Thau, France). Oceanol. Acta, 14 : (5), 473-488.

Jongman, R. H; Ter Braak, C. J. F. and Van Tongeren, O. F. R. (1987), Data analysis in community and landscape ecology. Pudoc, Wageningen. 303 pp.

Konrath, J. (1995), Flutuação temporal da taxa de fixação de carbono particulado, estrutura do fitoplâncton e fatores ambientais em uma lagoa costeira eutrófica (Lagoa Caconde, Osório, RS). Dissertação (Mestrado), Universidade Federal do Rio Grande do Sul, Porto Alegre, RS. 146 pp.

Kremer, L. M. (1985), Produção primária do fitoplâncton na Lagoa das Pombas Tramandaí, Rio Grande do Sul. Dissertação (Mestrado), Universidade Federal do Rio Grande do Sul, Porto Alegre, RS. 149 pp.

Lorenzen, C. J. (1967), Determination of chlorophyll and pheopigments: spectrophotometric equations. Limnol. Oceanog., 12, 343-346.

Medeiros, P. R. P. (1992), Estudo do Sistema LagunarEstuarino de Tramandaí-Imbé: Física e Química da Água. Dissertação (Mestrado), Universidade Federal do Rio Grande do Sul, Porto Alegre, RS. 112 pp.

Moed, J. R. and Hallegraeff, G. M. (1978), Some problems in the estimation of chlorophyll-a and phaeopigments from pre- and post-acidification spectrophotometric measurements. Int. Revue ges. Hydrobiol., 63 : (6), 787-800.

Moon, C. and Dunstan, W. (1990), Hydrodynamic trapping in the formation of the chlorophyll $a$ peak in turbid, very low salinity waters of estuaries. $J$. Plankton Res., 12 : (2), 323-336.

Moreira, A. L. C. (1989), Estados tróficos da Lagoa de Saquarema (RJ) num ciclo anual. Niterói. Dissertação (Mestrado), Universidade Federal Fluminense, Niterói, RJ, Brasil. 91 pp.

Riemann, B. (1978), Carotenoid interference in the spectrophotometric determination of chlorophyll degradation products from natural populations of phytoplankton. Limnol. Oceanogr., 23 : (5), 1059-1066.

Salomoni, E. S. (1997), Aspectos da limnologia e poluição das Lagoas costeiras Marcelino, Peixoto e pinguela (Osório, RS): uma abordagem baseada no fitoplâncton. Dissertação (Mestrado), Universidade Federal do Rio Grande do Sul, Porto Alegre, RS. 141 pp.
Spohr-Bacchin, M. (1994), A comunidade zooplanctônica da lagoa Emboaba, Tramandaí, RS: estrutura e variação sazonal. Dissertação (Mestrado), Universidade Federal do Rio Grande do Sul, Porto Alegre, RS. 112 pp.

Vélez, E.. (1990), Variação sazonal da produção primária, biomassa e composição do fitoplâncton da Lagoa Emboaba, Osório, RS. Monografia (Bacharelado), Universidade Federal do Rio Grande do Sul, Porto Alegre, RS. 153 pp.

Vollenweider, R. A. (ed.) (1974), A manual on methods for measuring primary production in aquatic environments. 2. ed. Oxford : Blackwell scientific publications (IBP Handbook, 12). 196 pp.

Vörös, L. and Padisák, J. (1991), Phytoplankton biomass and chlorophyll- $a$ in some shallow lakes in central Europe. Hydrobiologia, 215, 111-119.

Received: March 10, 2002; Revised: December 26, 2002; Accepted: November 20, 2003. 